annityat

JURNAL PENELITIAN BAHASA, SASTRA, DAN

BUDAYA ARAB

P-ISSN: 2615-7241 | E-ISSN: 2721-480X // Vol. 1 No. 1 | 1-16

() https://ejournal.upi.edu/index.php/alsuniyat/index

\title{
PENINGKATAN PENGUASAAN KOSAKATA BAHASA ARAB MELALUI PENGGUNAAN MEDIA WORD WALL
}

\author{
Hanifah Nur Azizah \\ Madrasah Ibtidaiyyah Al-Ba'ats Sumedang, Indonesia \\ Email: hanifahnurazizah1@gmail.com
}

\begin{abstract}
:
Application of the word wall method is one of alternative to improve students Arabic vocabulary. A problem for student of class III A in MI Al-Ba'ats is the low of Arabic vocabulary which has an impact on the students learning outcomes. The aim of this skills research are to improve of students Arabic vocabulary skills by using word wall media. This research used the Classroom Action Research (CAR) with fourth cycles. Each cycles concisted of six phases, which: identification of problems, need assessment, idea, implication, and decision making. The subject of the research are 21 students of the class III A MI Al-Ba'ats. The data sources of the research are the research and students. Data collection techniques are used an observation, an interview, tests and documentation. If the individual completeness reaches $\geq 65$ and if value of the whole completeness reaches $75 \%$ of the students more than $\geq 65$, then it could he said as a complete learning outcomes. The average value of learning outcomes in the pre-action is 62 and the value of the whole completeness is 33.3\%. The average value of learning outcomes in the first cycle 69 and the value of the whole completeness is $66.7 \%$. The average value of learning outcomes in the second cycle is 73 and the value of the whole completeness is $85.7 \%$. The average value of learning outcomes in the third cycle is 80 and the value of the whole completeness is $95.2 \%$. The average value of learning outcomes in the fourth cycle is 80,1 and the value of the whole completeness is $95.2 \%$. The conclution of this research is by using word wall media, it can improve students Arabic vocabulary skills at class III A of MI Al-Ba'ats.
\end{abstract}

\section{Keywords:}

Clasroom Action Research (CAR); Vocabulary; Word wall

\begin{abstract}
Abstrak:
Penggunaan media word wall merupakan salah satu media alternatif untuk meningkatkan penguasaan kosakata bahasa Arab. Sebagaimana permasalahan pada siswa kelas III A MI Al-Ba'ats yaitu rendahnya penguasaan kosakata bahasa Arab yang berdampak pada rendahnya hasil belajar bahasa Arab siswa. Penelitian ini bertujuan untuk meningkatkan penguasaan kosakata bahasa Arab melalui media pembelajaran word wall pada siswa kelas III A MI Al-Ba'ats. Bentuk penelitian ini adalah Penelitian Tindakan Kelas (PTK) yang dilaksanakan dalam empat siklus. Setiap siklus terdiri dari 6 tahapan tindakan, yaitu: definisi masalah, assessment kebutuhan, gagasan, implementasi, evaluasi, dan keputusan. Subjek penelitian ini adalah siswa kelas III MI Al-Ba'ats yang berjumlah 21 siswa. Sumber data yang digunakan berasal dari guru dan siswa. Teknik pengumpulan data yang digunakan adalah observasi, wawancara, tes, dan dokumentasi. Hasil belajar dikatakan tuntas apabila ketuntasan individual mencapai 65 dan ketuntasan klaksikal 75\% dari seluruh siswa dalam satu kelas memperoleh nilai $\geq 65$. Rata-rata hasil belajar pra siklus sebesar 62 dengan ketuntasan belajar klaksikal sebesar 33.3\%. Pada siklus I, nilai rata-rata kelas 69 dengan ketuntasan belajar klaksikal sebesar 66.7\%. Pada siklus II, nilai rata-rata kelas 73 dengan ketuntasan belajar klaksikal sebesar 85.7\%. Pada siklus III, nilai rata-rata kelas 80 dengan ketuntasan belajar klaksikal sebesar 95.2\%. Pada siklus IV, nilai ratarata kelas 80,1 dengan ketuntasan belajar klaksikal sebesar 95.2\%. Simpulan penelitian ini adalah penggunaan media pembelajaran word wall dapat meningkatkan penguasaan kosakata bahasa Arab siswa kelas III A MI Al-Ba'ats.
\end{abstract}

Kata Kunci:

Penelitian Tindakan Kelas (PTK); Kosakata; Word wall 


\section{PENDAHULUAN}

Berbahasa tidak terlepas dari kosakata. Kosakata merupakan salah satu unsur bahasa terpenting yang harus dimiliki oleh seseorang dalam mempelajari bahasa asing, begitu pun bahasa Arab (Muna 2011:45). Tiga unsur bahasa tersebut, yakni suara/pelafalan (fonologi), kosakata (leksikon), dan struktur kalimat (sintaksis). Ketika seseorang mempelajari bahasa Arab, tahap awal yang dipelajari ialah kosakata, karena tidak mungkin seseorang menguasai bahasa Arab tanpa mempelajari kosakata bahasa Arab.

Perbendaharaan kosakata bahasa Arab yang mencukupi tentunya dapat menunjang seseorang berkomunikasi dan menulis dengan bahasa Arab. Dengan demikian, penguasaan kosakata dianggap penting baik dari segi proses pembelajaran suatu bahasa ataupun pengembangan kemampuan seseorang dalam suatu bahasa yang akan dikuasainya. Kualitas keterampilan berbahasa seseorang bergantung kepada kuantitas dan kualitas kosakata yang dimilikinya, semakin kaya kosakata yang kita miliki semakin besar pula kemungkinan kita terampil berbahasa (Tarigan, 2011:12).

Dalam pembelajaran kosakata (mufrodat), pengajarannya bukan hanya sekedar mengajarkan kosakata kemudian menyuruh siswa untuk menghafal. Akan tetapi, siswa dianggap mampu menguasai mufrodat jika sudah mencapai idikator-indikator penguasaan mufrodat, beberapa indikator penguasaan mufrodat yang dikemukakan Mustofa di bawah ini.

1) Siswa mampu menerjemahkan bentuk-bentuk mufrodat dengan baik.

2) Siswa mampu mengucapkan dan menulis kembali mufrodat dengan baik dan benar.

3) Siswa mampu menggunakan mufrodat dalam jumlah (kalimat) dengan benar, baik dalam bentuk ucapan maupun tulisan (2011:60).

Dalam pembelajaran kosakata bahasa Arab di sekolah, salah satu media yang dapat digunakan untuk meningkatkan penguasaan kosakata bahasa Arab adalah media word wall. Word wall atau dinding kata merupakan kumpulan kosakata yang terorganisir secara sistematis yang ditampilkan dengan menggunakan huruf yang besar dan ditempelkan pada dinding suatu kelas. Media ini didesain untuk meningkatkan kegiatan kelompok belajar dan juga dapat melibatkan siswa dalam pembuatannya serta dalam aktivitas penggunaannya.

MI Al-Ba'ats merupakan salah satu sekolah yang menyertakan bahasa Arab sebagai salah satu mata pelajaran pada kurikulumnya. Menurut pemantauan peneliti saat melakukan observasi melalui wawancara dengan guru bahasa Arab, peneliti mendapati beberapa faktor 
penyebab kurangnya penguasaan kosakata bahasa Arab, yakni: metode pembelajaran yang monoton (konvensional) yang cenderung memusatkan guru sebagai pusat perhatian dalam pembelajaran, serta penggunaan model dan media pembelajaran yang kurang variatif dan efektif. Kondisi ini tentunya sangat berpengaruh pada tingkat penguasaan materi termasuk penguasaan kosakata.

Pada pembelajaran kosakata, guru memerintahkan siswa untuk menghafal kosakata yang ditulis di papan tulis, kemudian guru memerintah salah satu siswa untuk menyebutkan satu kosakata yang diingatnya, begitu pun berlanjut kepada siswa yang lain. Guru cenderung tidak menggunakan media yang variatif. Sedangkan untuk meningkatkan penguasaan kosakata, pembelajaran harus dilakukan secara interaktif, inspiratif, dan menyenangkan ditunjang dengan penggunaan media yang dapat memotivasi siswa untuk berpartisipasi aktif.

Proses dari belajar dan pembelajaran diharapkan memperoleh hasil yang optimal terutama pada hasil belajar siswa. Jika hasil belajar tidak optimal atau bahkan di bawah Kriteria Ketuntasan Minimal (KKM), berarti ada masalah di dalam proses pembelajaran. Masalah tersebut dapat berasal dari guru, siswa, dan sarana prasarana yang tersedia di sekolah yang mendukung proses pembelajaran. Permasalahan yang berasal dari siswa diantaranya: rendahnya hasil belajar siswa pada mata pelajaran bahasa Arab, kurangnya minat siswa belajar bahasa Arab, serta anggapan siswa bahwa bahasa Arab sulit dipelajari.

Pada tes awal yang dilakukan peneliti terhadap siswa kelas III MI Al-Ba'ats mengenai penguasaan kosakatanya, beberapa siswa kurang memiliki perbendaharaan kosakata yang cukup. Selain itu, beberapa siswa masih kurang pandai membaca bahasa Arab, sehingga pemilihan media word wall akan tepat untuk meningkatkan penguasaan kosakata siswa termasuk meningkatkan keterampilan membaca bahasa Arab siswa. Sebagaimana menurut (Galuh, 2012), yang menjelaskan bahwa media word wall terbukti efektif dalam meningkatkan hasil belajar siswa. Hal ini terlihat dari perolehan rata-rata hasil belajar kelas eksperimen yang lebih tinggi daripada kelas kontrol, meskipun selisihnya tidak terlalu jauh berbeda. Selain itu, (Pratama, 2016), menjelaskan terjadinya peningkatan pemahaman kosakata pada pembelajaran bahasa Jawa dengan menggunakan media word wall.

Dari kedua penelitian tersebut, kajian penelitian pertama dan kedua hanya memfokuskan penelitian pada peningkatan hasil belajar siswa dalam pembelajaran kosakata dengan menggunakan media word wall. Sementara itu, penelitian yang dilakukan peneliti tidak hanya memfokuskan penelitian pada hasil belajar kosakata bahasa Arab dengan 
menggunakan media word wall, namun menitikberatkan pada standar kompetensi membaca siswa yang cenderung masih terbata-bata dalam membaca teks bahasa Arab, dan bagaimana pengaruhnya media tersebut terhadap membaca bahasa Arab. Selain itu, penelitian yang telah banyak dilakukan yaitu pada pembelajaran bahasa Inggris, bahasa Jepang, dan pada tingkat tinggi, peneliti masih jarang menemukan penelitian pada pembelajaran bahasa Arab, terutama pada tingkat sekolah Dasar.

Berdasarkan permasalahan tersebut, peneliti hendak membuat solusi untuk meningkatkan penguasaan kosakata bahasa Arab dengan menggunakan media pembelajaran word wall. Kata media berasal dari bahasa latin merupakan jamak dari kata medium, secara harfiah kata tersebut mempunyai arti perantara atau pengantar.

Menurut Kustandi dan Sudjipto (2011:9), media adalah alat yang membantu proses belajar mengajar dan berfungsi untuk memperjelas makna pesan yang disampaikan sehingga dapat mencapai tujuan pembelajaran yang lebih baik. Media pembelajaran merupakan sarana yang dipergunakan atau dimanfaatkan agar pengajaran dapat berlangsung dengan baik, memperdekat atau memperlancar jalan ke arah tujuan yang telah direncanakan (Alwi, 2017:148). Media pembelajaran merupakan segala sesuatu yang dapat menyalurkan pesan, dapat merangsang pikiran, perasaan, dan kemauan peserta didik sehingga dapat mendorong terciptanya proses belajar pada diri peserta didik. Secara umum manfaat media pembelajaran adalah memperlancar interaksi antara guru dan siswa sehingga kegiatan pembelajaran lebih efektif dan efisien, proses pembelajaran menjadi lebih jelas dan menarik (Fajriah, 2015:110).

\section{METODE}

Penelitian Tindakan Kelas (Classroom Action Research) ini menggunakan desain penelitian yang dikembangkan oleh Mc.Kernant (dengan modifikasi dari Hopkins, 2011, hlm. 96).

Pola dasar bentuk siklus dalam PTK menurut Mc.Kernant disajikan sebagaimana gambar berikut: 


\section{Gambar 1: Desain PTK Mc.Kernant}

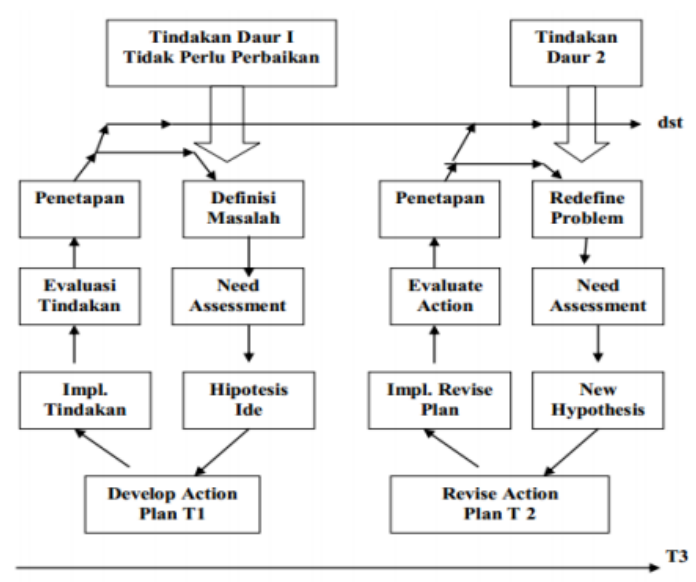

(Sumber: Ningrum, 2015, hlm. 55)

Lokasi penelitian bertempat di MI Al-Ba'ats yang beralamat di Jln. Lebak Jati Rancakalong km 3 Cimasuk I RT 01 RW 07 Desa Pamulihan Kecamatan Pamulihan Kabupaten Sumedang.

Sumber data dalam penelitian ini adalah siswa Kelas III yang merupakan sumber data primer yang berjumlah 21 orang dengan kolabolator Bapak Kurnia selaku guru kelas III A MI Al-Ba'ats yang merangkap guru mata pelajaran bahasa Arab. Adapun teknik pengumpulan data yang dilakukan oleh peneliti sebagaimana berikut ini.

1) Observasi

Observasi ini dilakukan dengan menggunakan instrumen lembar observasi siswa dan lembar observasi guru, kedua instrumen ini digunakan pada siklus I, II, III, dan IV penelitian.

2) Wawancara

Wawancara dilakukan dengan guru dan beberapa siswa di luar jam pelajaran. Wawancara diperlukan untuk mengetahui kondisi pembelajaran kosakata yang dialami oleh guru dan siswa.

3) Tes

Tes dilakukan untuk mengetahui perkembangan penguasaan kosakata serta membaca bahasa Arab yang dimiliki siswa. Instrumen tes ini dibuat dengan mempertimbangkan indikator penguasaan kosakata bahasa Arab dan implementasinya dalam membaca bahasa Arab.

4) Dokumentasi 
Pengumpulan data dilakukan dengan merekam kegiatan pembelajaran dengan menggunakan media foto.

Ada dua bentuk data yang dikumpulkan dalam penelitian ini, yaitu:

1) Data kuantitatif

Teknik kuantitatif digunakan untuk mengetahui peningkatan hasil belajar siswa selama proses pembelajaran yang diperoleh dari mengerjakan tes.

2) Data kualitatif

Data kualitatif diperoleh dari hasil observasi dengan menggunakan lembar observasi, wawancara, dan dokumentasi.

Dalam menganalisis data dan persentase ketuntasan belajar digunakan analisis data kuantitatif dengan rumus sebagai berikut:

$$
\% \text { Tuntas }=\frac{\Sigma T B}{N} \times 100 \%
$$

Ket:

$\Sigma T B \quad$ : Banyak siswa tuntas belajar

N : Banyak siswa seluruhnya

(Sudjana, 2015).

Penelitian mengenai penggunaan media word wall untuk meningkatkan penguasaan kosakata bahasa Arab siswa kelas III Al-Ba'ats dikatakan berhasil apabila terjadi perkembangan proses aktivitas siswa pada setiap siklus penelitian, serta peningkatan hasil penguasaan kosakata ini mencapai $75 \%$ dengan ketuntasan minimal skor individu setiap siswa adalah 65. Apabila kriteria tersebut telah terpenuhi, maka siklus penelitian berhenti dan dinyatakan berhasil.

\section{HASIL DAN PEMBAHASAN}

\section{Pra Siklus}

Pada tahap awal penelitian pra siklus, guru terlebih dulu mempersiapkan RPP yang sama dengan RPP yang digunakan pada tahun ajaran sebelumnya (2018/2019). RPP yang digunakan mengacu pada kurikulum 2013. Dalam pelaksanaan pembelajaran bahasa Arab, pertama-tama yang dilakukan guru yaitu membaca kosakata, kemudian siswa mengikuti kosakata yang telah dibacakan oleh guru, selanjutnya siswa dibimbing untuk membaca dan menghapal, di akhir pembelajaran siswa diberi latihan soal. Pembelajaran seperti ini tentu monoton jika dilakukan berulang-ulang tanpa menggunakan media yang menarik.Jika 
pembelajaran ditunjang dengan media yang interaktif dan membuat siswa aktif dari segala aspek, maka pembelajaran tidak akan monoton.

Penelitian tersebut membuktikan bahwa model pembelajaran yang didukung dengan pemanfaatan media pembelajaran menunjukkan dampak yang sangat signifikan terhadap kemampuan pembelajar memahami materi dibandingkan dengan system conventional instruction (Ritonga dkk, 2015:2).

Data hasil penelitian, rata-rata hasil belajar bahasa Arab yang mencakup indikator penguasaan kosakata pada pra siklus sebesar 62 dengan jumlah nilai 131 dan persentase ketuntasan klasikal 33.3\%. Hal ini menunjukkan bahwa siswa yang mencapai nilai KKM masih sangat kurang. Persentase penguasaan kosakata siswa pada akhir pembelajaran pra siklus dapat dilihat pada tabel 1:

Tabel 1: Hasil Penguasaan Kosakata Bahasa Arab Siswa pada Pra Siklus

\begin{tabular}{|c|c|c|c|c|}
\hline Nilai & Predikat & Keterangan & $\begin{array}{c}\text { Jumlah } \\
\text { Siswa }\end{array}$ & Persentase \\
\hline $89-100$ & A & Tuntas & 2 & $9.5 \%$ \\
\hline $77-88$ & B & Tuntas & 4 & $9.0 \%$ \\
\hline $65-76$ & C & Tuntas & 1 & $4.8 \%$ \\
\hline$>65$ & D & Tidak Tuntas & 14 & $66.7 \%$ \\
\hline & Jumlah & 21 & $100 \%$ \\
\hline
\end{tabular}

Berdasarkan tabel 1, hasil penguasaan kosakata bahasa Arab pada pra siklus dengan: predikat A (89-100) sebanyak 2 siswa, predikat B (77-88) sebanyak 4 siswa, predikat C (6576) sebanyak 1 siswa dan predikat D ( $>65$ ) sebanyak 14 siswa menujukkan bahwa ketuntasan belajar dari materi yang diajarkan pada pra siklus tanpa menggunakan media word wall dengan KKM 65 hanya 7 siswa, sedangkan siswa yang tidak tuntas berjumlah 14 siswa. Jika dipersentasekan jumlah siswa yang tuntas hanya 33.3\%. Hal ini menunjukkan bahwa siswa yang mencapai nilai KKM masih sangat kurang. Maka dari itu, perlu adanya upaya untuk meningkatkan hasil belajar siswa. Berdasarkan studi pustaka yang telah dilakukan, peneliti mencoba untuk menggunakan sebuah media pembelajaran yang akan membantu 
meningkatkan hasil belajar siswa dalam pembelajaran kosakata bahasa Arab. Sebagaimana yang dinyatakan oleh Susilana dan Cepi (2009:10), bahwa media pembelajaran bisa berfungsi untuk mempercepat proses belajar. Fungsi ini mengandung arti bahwa dengan media pembelajaran siswa dapat menangkap tujuan dan bahan ajar lebih mudah dan lebih cepat.

\section{Siklus I}

Setelah didapatkan hasil belajar pada pra siklus, selanjutnya dilakukan identifikasi masalah yang berkaitan dengan penguasaan kosakata bahasa Arab. Peneliti berkolaborasi dengan guru untuk menetapkan langkah-langkah yang akan dilakukan pada siklus I, dimulai dari perencanaan pembelajaran, pelaksanaan, hingga proses evaluasi pembelajaran. Berdasarkan hasil identifikasi masalah, maka didapatkan langkah untuk melaksanakan tindakan, yaitu belajar kosakata menggunakan media word wall.

Pada kegiatan inti pembelajaran, peneliti bersama guru menyampaikan materi dengan menggunakan media word wall. Saat menampilkan media ini, guru menggunakan permainan menebak kata. Permainan digunakan untuk penciptaan suasana belajar dari pasif ke aktif, dari kaku menjadi gerak (akrab) dan dari jenuh menjadi riang (Devi, 2010).

Guru bersama siswa terlebih dahulu membaca kosakata satu persatu pada media yang telah ditampilkan menggunakan bahasa Arab, guru meminta siswa mengulangi kosakata yang dibacakan oleh guru. Selanjutnya siswa diminta menebak kata (anggota wudhu) dengan menggunakan permainan.

Penggunaan media ini cukup meningkatkan keaktifan siswa dalam belajar. Berikut ini peneliti uraikan hasil keaktifan siswa: pada aspek aktif menghafal kosakata yaitu 77.38\% dengan kriteria aktif, keaktifan siswa dalam menjawab pertanyaan yaitu $78.57 \%$ dengan kriteria aktif dan keaktifan/serius mempelajari bahan ajar dengan media Word wall yaitu

Tabel 2: Hasil Penguasaan Kosakata Bahasa Arab Siswa pada Siklus I

\begin{tabular}{|c|c|c|c|c|}
\hline Nilai & Predikat & Keterangan & $\begin{array}{c}\text { Jumlah } \\
\text { Siswa }\end{array}$ & \% \\
\hline $89-100$ & A & Tuntas & 2 & $9.5 \%$ \\
\hline $77-88$ & B & Tuntas & 6 & $28.6 \%$ \\
\hline $65-76$ & C & Tuntas & 6 & $28.6 \%$ \\
\hline
\end{tabular}




\begin{tabular}{|c|c|c|c|c|}
\hline$>65$ & D & Tidak Tuntas & 7 & $33.3 \%$ \\
\hline \multicolumn{3}{|c|}{ Jumlah } & 21 & $100 \%$ \\
\hline
\end{tabular}

Berdasarkan data hasil belajar yang mencakup indikator penguasaan kosakata siswa pada akhir siklus I, nilai rata-rata siswa 69 dengan jumlah nilai 145 dan persentase ketuntasan klaksikal sebesar 66.7\%. Untuk lebih jelasnya, berikut ini peneliti uraikan hasil belajar siswa pada siklus I: predikat A (89-100) sebanyak 2 siswa, predikat B (77-88) sebanyak 6 siswa, predikat C (65-76) sebanyak 6 siswa dan predikat D $(>65)$ sebanyak 7 siswa. Hasil belajar pada siklus I ini mengalami peningkatan sebesar $33.4 \%$. Hal ini menunjukkan bahwa penggunaan media word wall dapat meningkatkan penguasaan kosakata bahasa Arab siswa. Namun ini masih kurang dari yang diharapkan oleh peneliti. Peneliti bersama guru melakukan perbaikan yang akan dilakukan pada siklus II dengan cara memotivasi siswa dalam belajar, meningkatkan keaktifan siswa dengan belajar berkelompok/diskusi.

\section{Siklus II}

Proses pembelajaran pada siklus II banyak perbaikan yang dilakukan oleh peneliti dan guru. Salah satunya untuk meningkatkan keaktifan siswa, tindakan yang dilakukan pada siklus II yaitu menggunakan metode diskusi dalam pembuatan serta penggunaan media word wall.

Pada siklus II, guru mencoba untuk mengelompokkan siswa dalam belajar kosakata bahasa Arab yang terdiri dari 4-5 orang siswa, selanjutnya guru membimbing siswa membaca dan menghafal 5 kosakata dengan bernyanyi. Melalui nyanyian/lagu ini diharapkan dapat menghilangkan kejenuhan siswa pada saat belajar dan memberikan kesenangan agar dapat meningkatkan penguasaan mufrodat atau menambah pembendaharaan mufrodat (Mustofa, 2011:73). Berikut ini hasil belajar siswa pada siklus II: 
Tabel 3: Hasil Penguasaan Kosakata Bahasa Arab Siswa Siklus II

\begin{tabular}{|c|c|c|c|c|}
\hline Nilai & Kategori & Keterangan & $\begin{array}{c}\text { Jumlah } \\
\text { Siswa }\end{array}$ & $\mathbf{\%}$ \\
\hline $89-100$ & $\mathrm{~A}$ & Tuntas & 6 & $28.6 \%$ \\
\hline $77-88$ & $\mathrm{~B}$ & Tuntas & 10 & $47.6 \%$ \\
\hline $65-76$ & $\mathrm{C}$ & Tuntas & 2 & $9.5 \%$ \\
\hline$>65$ & D & Tidak Tuntas & 3 & $14.3 \%$ \\
\hline & Jumlah & 21 & $100 \%$ \\
\hline
\end{tabular}

Dengan pengelompokkan siswa dalam belajar dan penggunaan nyanyian, hasil akhir pembelajaran didapatkan peningkatan yang signifikan dan persentase belajar meningkat sebanyak 19\%, dari keaktifan siswa didapatkan: aspek aktif menghafal kosakata yaitu 79.7\% dengan kriteria aktif, keaktifan siswa siswa dalam menjawab pertanyaan yaitu 78.5\% dengan kriteria aktif dan keaktifan/serius mempelajari bahan ajar dengan media word wall yaitu $73.8 \%$.

Nilai rata-rata yang diperoleh pada siklus II yaitu 73 dengan jumlah nilai 153 dan persentase ketuntasan klaksikal sebesar 85.7\% dengan uraian sebagai berikut: predikat A (89-100) sebanyak 6 siswa, predikat B (77-88) sebanyak 10 siswa, predikat C (65-76) sebanyak 2 siswa dan predikat D (>65) sebanyak 3 siswa. Hal ini menunjukkan bahwa pembelajaran bahasa Arab menggunakan media word wall setiap siklusnya mampu meningkatkan hasil belajar bahasa Arab siswa. Peneliti kembali melakukan penelitian pada siklus III serta melakukan beberapa perbaikan untuk mengukur apakah hasil belajar dapat meningkat kembali atau tidak. Meskipun hasil belajar pada siklus ini sudah mencapai hasil yang diharapkan, namun peneliti bersama guru belum merasa puas dengan hasil yang diperoleh. Karena pembelajaran yang dicapai siswarelatif harus stabil dan berimbang pada setiap siklusnya.

Pada siklus III, pelaksanaan proses pembelajaran kembali mengalami peningkatan yang signifikan. Pelaksanaan tindakan yang dilakukan pada siklus III tidak berbeda jauh 
ALSUNIYAT: Jurnal Penelitian Bahasa, Sastra, dan Budaya Arab

dengan tindakan pada siklus II. Guru kembali mengelompokkan siswa.

Tabel 4: Hasil Penguasan Kosakata Bahasa Arab Siswa Siklus III

\begin{tabular}{|c|c|c|c|c|}
\hline Nilai & Kategori & Keterangan & $\begin{array}{c}\text { Jumlah } \\
\text { Siswa }\end{array}$ & \% \\
\hline $89-100$ & A & Tuntas & 6 & $28.6 \%$ \\
\hline $77-88$ & B & Tuntas & 10 & $47.6 \%$ \\
\hline $65-76$ & C & Tuntas & 4 & $19.0 \%$ \\
\hline$>65$ & D & Tidak Tuntas & 1 & $4.8 \%$ \\
\hline & Jumlah & 21 & $100 \%$ \\
\hline
\end{tabular}

Dari hasil belajar siswa yang mencakup indikator penguasaan kosakata, hampir seluruh siswa mencapai ketuntasan belajar. Dari keseluruhan jumlah siswa, hanya tersisa 1 siswa (4.8\%) yang tidak mencapai ketuntasan belajar dan selebihnya atau 20 orang siswa (95.2\%) sudah tuntas. Berikut peneliti uraikan hasil belajar pada siklus III: predikat A (89100) sebanyak 6 siswa, predikat B (77-88) sebanyak 10 siswa, predikat C (65-76) sebanyak 4 siswa dan predikat D (>65) sebanyak 1 siswa. Dengan keaktifan siswa yang peneliti uraikan: aspek aktif menghapal kosakata yaitu $85.7 \%$ dengan kriteria aktif, keaktifan siswa dalam menjawab pertanyaan yaitu 79.7\% dengan kriteria aktif dan keaktifan/serius mempelajari bahan ajar dengan media word wall yaitu 76.1\% dengan kriteria aktif.

Perbandingan persentase penguasaan kosakata siswa pada siklus II dengan data pada siklus III terjadi peningkatan penguasaan kosakata siswa sebesar 9.5\%. Persentase kenaikan terpantau signifikan karena adanya peningkatan secara terus menerus dari siklus I sampai siklus III.

\section{Siklus IV}

Perbandingan persentase penguasaan kosakata siswa pada siklus III dengan data pada siklus IV tidak mengalalami peningkatan, namun jika dilihat dari rata-rata hasil belajar terjadi peningkatan dari 80 menjadi 80,1 dengan jumlah nilai 169 dan persentase ketuntasan klaksikal yang sama, yakni 95.2\%.

Jika dilihat dari hasil belajar siswa didapatkan hasil belajar yang peneliti uraikan pada table 5: 
Tabel 5: Penguasaan Kosakata Bahasa Arab Siswa Siklus IV

\begin{tabular}{|c|c|c|c|c|}
\hline Nilai & Kategori & Keterangan & $\begin{array}{c}\text { Jumlah } \\
\text { Siswa }\end{array}$ & \% \\
\hline $89-100$ & $\mathrm{~A}$ & Tuntas & 6 & $28.6 \%$ \\
\hline $77-88$ & $\mathrm{~B}$ & Tuntas & 9 & $42.8 \%$ \\
\hline $65-76$ & $\mathrm{C}$ & Tuntas & 5 & $23.8 \%$ \\
\hline$>65$ & $\mathrm{D}$ & Tidak Tuntas & 1 & $4.8 \%$ \\
\hline \multicolumn{3}{|c|}{ Jumlah } & 21 & $100 \%$ \\
\hline
\end{tabular}

Predikat A (89-100) sebanyak 6 siswa, predikat B (77-88) sebanyak 9 siswa, predikat C (65-76) sebanyak 5 siswa dan predikat D (>65) sebanyak 1 siswa. Persentase ketuntasan klaksikal pada siklus IV tidak mengalami peningkatan dengan perentase mencapai 95.2\%. Persentase kenaikan terpantau signifikan karena adanya peningkatan secara terus menerus dari siklus I sampai siklus IV, dan. Berdasarkan hal tersebut, maka peneliti memutuskan untuk tidak melanjutkan tindakan ke siklus berikutnya.Hasil belajar ini dapat dikatakan cukup dan berhasil jika melihat dari indikator pencapaian ketuntasan belajar klaksikal yang melebihi 75\%. Jika dilihat dari penggunaan media word wall yang telah dilakukan, maka dapat digambarkan melalui grafik di bawah ini, perkembangan yang telah dicapai pada tiap siklus untuk hasil belajar siswa.

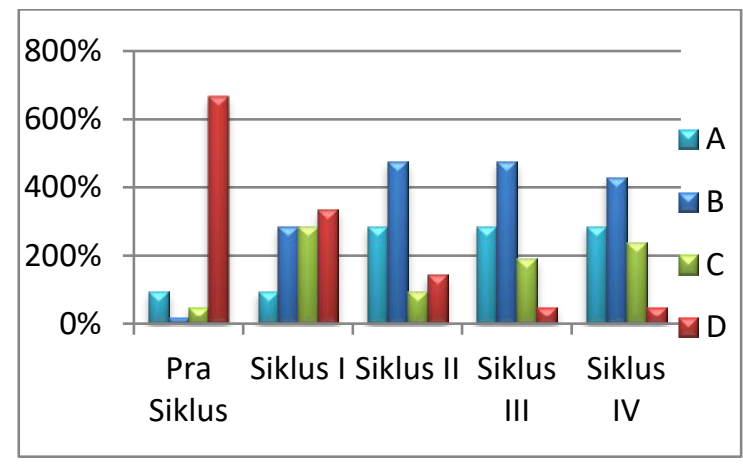

Grafik 1: Perkembangan Penguasaan Kosakata bahasa Arab dari pra siklus sampai siklus IV 
Berdasarkan grafik 1 dapat diketahui perkembangan penguasaan kosakata bahasa Arab siswa kelas III A MI Al-Ba'ats pada pra siklus hingga penggunaan media word wall pada siklus I, II, III, dan IV terjadi peningkatan. Dimana pada pra siklus hasil belajar siswa pada materi ketuntasan siswa dalam menjawab pertanyaan pada proses evaluasi baru mencapai 33.3\%, dengan predikat A 2 siswa atau 9.5\%, B 4 siswa atau 19.0\%, C 1 siswa atau 4.8\% dan D 14 siswa atau 66.7\%. Pada siklus I ketuntasan belajar siswa mencapai 66.7\% dengan predikat A 2 siswa atau 9.5\%, B 6 siswa 28.6\%, C 6 siswa atau 28.6\% dan predikat D 7 siswa atau 33.3\%. Pada siklus II ketuntasan belajar siswa mencapai 85.7\% dengan predikat A 6 siswa atau 28.5\%, B 10 siswa atau 47.6\%, C 2 siswa atau 9.5\% dan predikat D 3 siswa atau 14.3\%. Pada siklus III ketuntasan belajar siswa mencapai 95.2\% dengan predikat A 6 siswa 28.6\%, B 10 siswa atau 47.6\%, C 4 siswa atau 19.0\% 1 siswa atau 4.8\%. Pada siklus IV ketuntasan belajar siswa mencapai 95.2\% dengan predikat A 6 siswa 28.6\%, B 9 siswa atau 42.8\%, C 5 siswa atau 23.8\% 1 siswa atau 4.8\%.

Dilihat dari hasil belajar yang terus meningkat pada setiap siklusnya, peneliti menyimpulkan bahwa dengan menggunakan media pembelajaran akan mempercepat proses belajar, sebagaimana yang dinyatakan oleh Susilana dan Cepi (2009:10) bahwa media pembelajaran bisa berfungsi untuk mempercepat proses belajar. Fungsi ini mengandung arti bahwa dengan media pembelajaran siswa dapat menangkap tujuan dan bahan ajar lebih mudah dan lebih cepat.

\section{Keaktifan Siswa dalam Penguasaan Kosakata bahasa Arab Menggunakan Media Word wall}

Keaktifan siswa pada tiap siklusnya mengalami peningkatan. Untuk lebih jelasnya dapat dilihat pada grafik 2 .

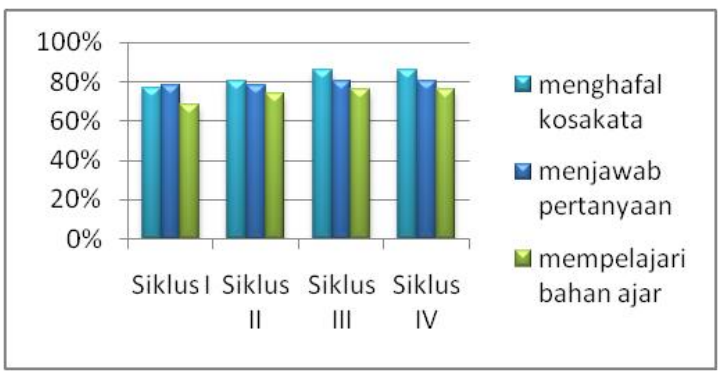

\section{Grafik 2: Perkembangan Keaktifan Siswa dari pra siklus sampai siklus IV}

Hasil ini menunjukkan bahwa apa yang telah dilakukan oleh peneliti bersama kolaborator dalam mengimplementasikan media pembelajaran word wall untuk 
meningkatkan penguasaan kosakata bahasa Arab siswa kelas IIIA MI Al-Ba'ats berhasil meningkatkan kekatifan siswa dalam belajar. Berdasarkan hasil penelitian ini, dimulai dari pelaksanaan pra siklus sampai dengan siklus IV dapat diketahui terjadi perubahan penguasaan dalam membaca kosakata Bahasa Arab, serta dalam memahami serta mengingat kosakata bahasa Arab pun lebih cepat hafal dan cepat ingat, dibandingkan dengan tidak menggunakan media. Penelitian telah membuktikan bahwa model pembelajaran yang didukung dengan pemanfaatan media pembelajaran menunjukkan dampak yang sangat signifikan terhadap kemampuan pembelajar memahami materi dibandingkan dengan system conventional instruction (Ritonga dkk, 2015:2).

Hasil pembelajaran kosakata bahasa Arab diatas dikatakan dapat dikuasai oleh siswa, hal ini sesuai dengan apa yang diungkapkan Mustafa mengenai indikator penguasaan kosakata yaitu bahwa siswa dianggap mampu menguasai mufrodat jika sudah mencapai indikator-indikator penguasaan mufrodat, berikut ini beberapa indikator penguasaan mufrodat:

1) siswa mampu menerjemahkan bentuk-bentuk mufrodat dengan baik.

2) siswa mampu mengucapkan dan menulis kembali mufrodat dengan baik dan benar.

3) siswa mampu menggunakan mufrodat dalam jumlah (kalimah) dengan benar, baik dalam bentuk ucapan maupun tulisan (2011:60).

Dengan demikian, peneliti dapat menyimpulkan bahwa usaha yang dilakukan peneliti bersama guru dalam mengimplementasikan media word wall yang dilaksanakan dengan empat siklus dapat meningkatkan penguasaan kosakata, hasil belajar dan keaktifan siswa.

Indikator yang ingin dicapai oleh peneliti dari penelitian ini yaitu meningkatkan penguasaan kosakata bahasa Arab siswa yang ditandai dengan hasil belajar dalam setiap pertemuannya sesuai dengan KKM 65. Gagasan yang menyatakan bahwa pembelajaran bahasa Arab menggunakan media word wall akan meningkatkan penguasaan kosakata bahasa Arab siswa kelas IIIA MI Al-Ba'ats diterima. Depdiknas (2008) menjelaskan bahwa indikator yang menunjukkan keberhasilan pembelajaran atau peningkatan hasil belajar siswa yaitu jika ketuntasan klaksikal minimal 75\%.

\section{SIMPULAN}

Dari hasil penelitian dan pembahasan penggunaan media word wall dalam pembelajaran kosakata bahasa Arab pada siswa kelas III A MI Al-Ba'ats dapat terlihat perkembangan pada hasil belajar siswa dari pra siklus sampai siklus IV. Hal ini terlihat dari 
perolehan rata-rata hasil belajar siswa yang terus meningkat. Sebelum dilaksanakannya penggunaan media word wall dalam pembelajaran kosakata bahasa Arab, nilai rata-rata kelas adalah 62. Hasil belajar dikatakan tuntas apabila ketuntasan individual mencapai 65 dan ketuntasan klaksikal 75\% dari seluruh siswa dalam satu kelas memperoleh nilai $\geq 65$. Nilai rata-rata kelas pada siklus I adalah 69 dengan ketuntasan belajar klaksikal sebesar 66.7\%. Pada siklus II, nilai rata-rata kelas 73 dengan ketuntasan belajar klaksikal sebesar 85.7\%. Pada siklus III, nilai rata-rata kelas 80 dengan ketuntasan belajar klaksikal sebesar 95.2\%. Pada siklus IV, nilai rata-rata kelas 80,1 dengan ketuntasan belajar klaksikal sebesar 95.2\%.

Berdasarkan hasil pengolahan data dapat diketahui bahwa pembelajaran kosakata bahasa Arab siswa menggunakan media word wall dinilai efektif. Hal tersebut terbukti dalam hasil belajar, bahwa dari hasil proses pembelajaran dikatakan berhasil apabila terjadi perubahan yang positif dari diri siswa seluruhnya atau setidak-tidaknya sebagiannya sebesar 75\%. Oleh karena itu, dapat disimpulkan bahwa penggunaan media Word wall dapat meningkatkan penguasaan kosakata bahasa Arab siswa kelas III A MI Al-Ba'ats.

\section{DAFTAR PUSTAKA}

Alwi, S. (2017). Problematika Guru Dalam Pengembangan Media Pembelajaran. Itqan: Jurnal Ilmu-ilmu Kependidikan. 8(2), 145-167. doi: http://ejurnal.iainlhokseumawe.ac.id/indek.phpp/itqan/article/rivew/107.

Bachry, dkk. (2018). Penggunaan media Word wall untuk meningkatkan kemampuan menulis tegak bersambung. Jurnal Pendidikan Luar Biasa.

Depdiknas. (2008). Penetapan Kriteria Ketuntasan minimal. Bandung: Direktorat Jenderal Manajemen Pendidikan Dasar dan Menengah.

Devi, P, K. (2010). Metode-metode dalam Pembelajaran IPA. PPPPTK IPA

Fajriah, Z. (2015). Peningkatan Penguasaan Kosakata Bahasa Arab (Mufradat) Melalui Penggunaan Media Kartu Kata Bergambar: Jurnal Pendidikan Usia Dini, 9(1), 107-126. doi: https://doi.org/10.21009/JPUD.091

Galuh, M, I. (2012). Efektivitas Penggunaan Word wall Sebagai Media Pembelajaran Kosakata Bahasa Jepang. (Skripsi). UPI.

Hopkins, D. (2011). Penelitian Tindakan Kelas. Bandung: Rosdakarya.

Kustandi, C \& Sudjipto, B. (2011). Media Pembelajaran; Manual dan Digital. Bogor: Ghalia Indonesia. 
ALSUNIYAT: Jurnal Penelitian Bahasa, Sastra, dan Budaya Arab

Majid, A. (2011). Perencanaan Pembelajaran Mengembangkan Standar Kompetensi Guru. Bandung: Remaja Rosdakarya.

Muna, W. (2011). Metodologi Pembelajaran Bahasa Arab (Teori dan Aplikasi) Yogyakarta: Penerbit Press

Mustofa, S. (2011). Strategi Pembelajaran Bahasa Arab Inovatif. Malang: UIN Press

Ritonga, dkk. (2016). Pembelajaran Bahasa Arab Berbasis Teknologi Informasi dan

Komunikasi di Kota Padang. Arabiyat; Jurnal Pendidikan Bahasa Arab dan Kebahasaaraban. 3(1). 1-12. doi: http:///dx.doi.org/10.15408/a.v3i1.2879

Sanjaya, W. (2016). Penelitian Tindakan Kelas. Jakarta: Prenada Media.

Sudjana, N. (2015). Penilaian Hasil Proses Belajar Mengajar. Bandung: PT Remaja Rosdakarya

Susilana, R. \& Cepi, R. (2009). Media Pembelajaran; Hakikat Pengembangan, Pemanfaatan, dan Penilaian. Bandung: CV Wacana Prima.

Supriyadi, R. (2015). Efektivitas Penggunaan Teknik Clustering Terhadap Peningkatan Keterampilan Siswa dalam Menulis Karangan Deskripsi (INSYA): Studi Eksperimen Kuasi Siswa Kelas XI Madrasah Aliyah Daarul Ulum Lido Bogor. (Tesis). UPI

Pratama. (2016). Peningkatan Pemahaman Kosakata Bahasa Jawa Melalui Media Word Wall Pada Siswa Kelas Vb Sd Negeri Madegondo 01 Grogol Sukoharjo Tahun Ajaran 2015/2016. Solo: UNS

Tarigan, H. (2011). Menyimak sebagai suatu Keterampilan Berbahasa. Bandung: Angkasa

Zahra. (2012). Pentingnya Membangun Apersepsi Bagi Pengajar. [Online]. Tersedia: http//zahrathelittledesert.blog.uns.ac.id/2011/07/19/petingnya-membangunapersepsi-bagi-pengajar-/ (Oktober 2019)

Vol. 1 No. $1 \mid 1-16$

ALSUNIYAT, p-ISSN: 2615-7241, e-ISSN: 2721-480X 